Marquette University

e-Publications@Marquette

4-14-2009

\title{
Subunit-Selective Interrogation of CO Recombination in Carbonmonoxy Hemoglobin by Isotope-Edited Time-Resolved Resonance Raman Spectroscopy
}

Gurusamy Balakrishnan

Princeton University

Xiaojie Zhao

Princeton University

Edyta Podstawska

Jagiellonian University

Leonard M. Proniewicz

Jagiellonian University

James R. Kincaid

Marquette University, james.kincaid@marquette.edu

See next page for additional authors

Follow this and additional works at: https://epublications.marquette.edu/chem_fac

Part of the Chemistry Commons

\section{Recommended Citation}

Balakrishnan, Gurusamy; Zhao, Xiaojie; Podstawska, Edyta; Proniewicz, Leonard M.; Kincaid, James R.; and Spiro, Thomas G., "Subunit-Selective Interrogation of CO Recombination in Carbonmonoxy Hemoglobin by Isotope-Edited Time-Resolved Resonance Raman Spectroscopy" (2009). Chemistry Faculty Research and Publications. 391.

https://epublications.marquette.edu/chem_fac/391 
Authors

Gurusamy Balakrishnan, Xiaojie Zhao, Edyta Podstawska, Leonard M. Proniewicz, James R. Kincaid, and Thomas G. Spiro

This article is available at e-Publications@Marquette: https://epublications.marquette.edu/chem_fac/391 


\title{
Subunit-Selective Interrogation of CO Recombination in Carbonmonoxy Hemoglobin by Isotope-Edited Time-resolved Resonance Raman Spectroscopy
}

\author{
Gurusamy Balakrishnan* \\ Department of Chemistry, Princeton University, \\ Princeton, NJ \\ Xiaojie Zhao** \\ Department of Chemistry, Princeton University, \\ Princeton, NJ \\ Edyta Podstawska \\ Department of Chemistry, Marquette University, \\ Milwaukee, WI \\ Department of Chemistry, Jagiellonian University, \\ Krakow, Poland \\ Leonard M. Proniewicz \\ Department of Chemistry, Marquette University, \\ Milwaukee, WI \\ Department of Chemistry, Jagiellonian University, \\ Krakow, Poland
}

Biochemistry, Vol 48, No. 14 (April 14, 2009): pg. 3120-3126. DOI. This article is (c) American Chemical Society and permission has been granted for this version to appear in e-Publications@Marquette. American Chemical Society does not grant permission for this article to be further copied/distributed or hosted elsewhere without the express permission from American Chemical Society. 


\author{
James R. Kincaid \\ Department of Chemistry, Marquette University, \\ Milwaukee, WI \\ Thomas G. Spiro* \\ Department of Chemistry, Princeton University, \\ Princeton, NJ
}

\begin{abstract}
Hemoglobin is an allosteric tetrameric protein made up of a $\beta$ hetero-dimers. The $a$ and $\beta$ chains are similar, but are chemically and structurally distinct. To investigate dynamical differences between the chains, we have prepared tetramers in which the chains are isotopically distinguishable, via reconstitution with ${ }^{15} \mathrm{~N}$-heme. Ligand recombination and heme structural evolution, following $\mathrm{HbCO}$ dissociation, was monitored with chain selectivity by resonance Raman (RR) spectroscopy. For a but not for $\beta$ chains, the frequency of the $\mathrm{V}_{4}$ porphyrin breathing mode increased on the microsecond time scale. This increase is a manifestation of proximal tension in the $\mathrm{Hb} \mathrm{T}$-state, and its time course is parallel to the formation of $\mathrm{T}$ contacts, as determined previously by UVRR spectroscopy. Despite the localization of proximal constraint in the a chains, geminate recombination was found to be equally probable in the two chains, with yields of $39 \pm 2 \%$. We discuss the possibility that this equivalence is coincidental, in the sense that it arises from the evolutionary pressure for cooperativity, or that it reflects mechanical coupling across the $a \beta$ interface, evidence for which has emerged from UVRR studies of site-mutants.
\end{abstract}

Hemoglobin continues to offer a compelling laboratory for the study of allostery in proteins. Ligand binding induces a shift in the $\mathrm{Hb}$ tetramer from a low- $(T)$ to a high-(R) affinity structure,,$^{-\underline{-3}}$ but analysis of this process is complicated by the fact that the tetramer is composed of hetero-dimers, $a \beta$. The $a$ and $\beta$ chains are similar, but distinct. Much evidence points to differing constraints on ligand binding in the $\mathrm{T}$ state. In the a chains the Fe atom is restrained by its proximal histidine ligand from readily approaching the heme plane in order to bind a distal ligand. This constraint is at the core of Perutz' stereochemical trigger mechanism for allostery. ${ }^{4}$ In the deoxy form, the Fe atom is five-coordinate and high-spin, and non-bonded forces drive it out of the heme plane toward the proximal ligand. Binding of the diatomic ligands $\mathrm{O}_{2}, \mathrm{NO}$ or $\mathrm{CO}$ requires the $\mathrm{Fe}$ to approach the heme plane, and it becomes low-spin. Constraint on this motion by the

Biochemistry, Vol 48, No. 14 (April 14, 2009): pg. 3120-3126. DOI. This article is (c) American Chemical Society and permission has been granted for this version to appear in e-Publications@Marquette. American Chemical Society does not grant permission for this article to be further copied/distributed or hosted elsewhere without the express permission from American Chemical Society. 
protein lowers the ligand affinity, while overcoming the constraint induces changes in the protein structure and alters contacts at the subunit interfaces, thereby destabilizing the $T$ state.

However, the indicators of proximal constraint are attenuated in the $\beta$ chain, which appear to be more flexible than the a chain. $\frac{5}{\text { On the }}$ other hand, the distal binding pocket is more crowded in the T state for the $\beta$ than for the a chain, leading Perutz to suggest an ordered sequence of ligand binding, first to the $a$ and then to the $\beta$ chains, the latter following the T-R conversion. 4

Since then there have been a number of studies attempting to distinguish a from $\beta$ chain reactivity. ${ }^{6}$ All appear to show a surprising degree of functional similarity between the two kinds of subunits, even though structural and spectroscopic differences persist. However, most of these studies have employed hybrid constructs, in which a or $\beta$ chains are substituted with metal ions that do not bind the ligand under study, in order to isolate the behavior of the functional Fecontaining chain. $\underline{6}-\underline{19}$ Although structural integrity is maintained in these hybrids, there are nevertheless questions about indirect effects of chemical substitution. Seeking to address the issue of $a / \beta$ equivalence in the native protein, we have employed chain-specific isotope labeling, reconstituting $\mathrm{Hb}$ with heme having ${ }^{15} \mathrm{~N}$ in the pyrrole rings. Time-resolved resonance Raman (RR) spectroscopy was then used to monitor dynamics at the heme following $\mathrm{HbCO}$ photodissociation. The heme RR spectrum can distinguish a from $\beta$ heme because the vibrational bands are isotope-sensitive

We find that $\mathrm{CO}$ recombination rates and geminate recombination yields are indistinguishable for the $a$ and $\beta$ chains. However, the spectra also show a differing structural response of the two chains. We consider the possibility that the functional equivalence is a reflection of intra-dimer coupling between the two heme sites, or rather that chain-selective evolutionary changes lead to the same function for individual chains.

Biochemistry, Vol 48, No. 14 (April 14, 2009): pg. 3120-3126. DOI. This article is (c) American Chemical Society and permission has been granted for this version to appear in e-Publications@Marquette. American Chemical Society does not grant permission for this article to be further copied/distributed or hosted elsewhere without the express permission from American Chemical Society. 


\section{Materials and Methods}

\section{Sample Preparation}

${ }^{15} \mathrm{~N}$-ferriprotoporphyrin IX chloride $\left({ }^{15} \mathrm{~N}-\mathrm{Fe}^{\mathrm{III}}(\mathrm{PPIX}) \mathrm{Cl}\right)$ was graciously provided by Professor Kevin Smith and used after checking for purity via thin-layer chromatography (TLC), proton NMR and electronic absorption spectroscopy. $\underline{20}-\underline{22}$ Sodium $p$ (hydroxymercuri)benzoate (PMB) and sodium perchlorate were purchased from Aldrich Chemical Company and used without further purification. Bio-gel P-6DG (Bio-Rad Laboratories, Hercules, CA), CM cellulose (CM-52) and diethylaminoethyl cellulose (DE-53) (Whatman, Fairfield, NJ) were used for protein column chromatography.

\section{Protein Preparation}

Hemoglobin $(\mathrm{Hb})$ was isolated from red blood cells according to established procedures 23 and stored as the $\mathrm{CO}$ adduct. ApoHb was prepared by the acidacetone method ${ }^{24}$ and reconstitution with ${ }^{15} \mathrm{~N}$ isotopically labeled protoheme, to form ${ }^{15} \mathrm{~N}-\mathrm{Hb}$, was accomplished as described previously, $23, \underline{25}, \underline{26} \mathrm{Hb}$ and ${ }^{15} \mathrm{~N}-\mathrm{Hb}$ were dissociated into their subunits by reaction with $\mathrm{PMB}^{27}$ and isolated as reported in the literature. $\underline{25}$ Isotopically labeled hybrids were obtained as the carbon monoxide adducts by incubating the proper subunits; i.e., $\mathrm{a}_{\mathrm{N} 15}{ }^{\mathrm{CO}}$ and $\beta_{\mathrm{N} 14}{ }^{\mathrm{CO}}$. The same was done for the $\mathrm{a}_{\mathrm{N} 14}{ }^{\mathrm{CO}}$ and $\beta_{\mathrm{N} 15}{ }^{\mathrm{CO}}$ subunits. Purification was accomplished by column chromatography. $\underline{25}-\underline{27}$

\section{Spectroscopy}

Time-resolved resonance Raman (TR3)

The $\mathrm{TR}^{3}$ spectroscopic setup has been described elsewhere. $\underline{28, \underline{29}}$ Briefly, photolysis pulses at $419 \mathrm{~nm}$ (20 ns, $60 \mu \mathrm{J} /$ pulse, $1 \mathrm{kHz}$ ) were generated by frequency doubling the output of a Ti-Sapphire laser (Photonics International Industries), which was pumped (527 nm, 10 $\mathrm{mJ} /$ pulse, $70 \mathrm{~ns}, 1 \mathrm{kHz}$ ) by an intracavity frequency-doubled Nd-YLF laser (GM30, Photonics International Inc). Probe pulses (20 ns, $1 \mathrm{kHz}$ ) at $426 \mathrm{~nm}(0.5 \mu \mathrm{J} /$ pulse $)$ were obtained by frequency doubling a second Ti-Sapphire laser. Scattered light was collected at $135^{\circ}$ with a 
pair of fused quartz lenses, f-matched to a $1.26 \mathrm{~m}$ spectrograph (Spex 1269), which was equipped with a holographic grating (3600 groove $\mathrm{mm}^{-1}$ ) and intensified photodiode-array detector (IPDA-1024 S/B, Roper Scientific). A time-delay signal generator (DG535, Stanford Research) was used to control the delay time between pump and probe pulses and synchronize the Raman scattered signals from the probe pulse with the gate of the detector. Interfering signals from the pump laser were eliminated by electronically gating the detector using a high voltage pulse generator (Roper Scientific, PG201). The timeresolution of the current set up is limited to 200 ns by the minimum gate-width of the IPDA intensifier at $1 \mathrm{kHz}$. The probe pulse wavelength, $426 \mathrm{~nm}$, was selected to provide comparable resonance enhancement for the $\mathrm{v}_{4} \mathrm{RR}$ bands of deoxyHb and $\mathrm{HbCO}$.

HbCO samples having a concentration of $\sim 0.25 \mathrm{mM}$ in heme were prepared using CO-saturated phosphate buffer $(\mathrm{pH} 7.5,50 \mathrm{mM})$. About $350 \mu$ of sample solution was contained in a $5 \mathrm{~mm}$ glass NMR tube and spun around a stationary stirring wire to ensure vertical mixing of the sample. A CO atmosphere was maintained near the top surface of the sample during the entire experiment by continuous delivery of water saturated $\mathrm{CO}$, under a vacuum exhaust. The diameters of the pump and probe laser spots at the samples were estimated to be $\sim 80$ and $60 \mu \mathrm{m}$ respectively and the diameter of the NMR tube was $5 \mathrm{~mm}$. To avoid spatial overlap mismatch between pump and probe laser spots, and to ensure that successive pulses excited a new sample volume, the spinning speed of the NMR tube (monitored on-line by a tachometer (08210, Cole Parmer)) was adjusted to $800 \mathrm{rpm}$ for $200 \mathrm{~ns}$ to $3 \mu \mathrm{s}$ time delays, $500 \mathrm{rpm}$ for 6 to 50 us delays, and 300 rpm for longer delay times. Sample integrity was checked by the reproducibility of Raman and absorption spectra.

\section{$R R$ cross section measurement}

The Raman set-up used for static RR measurements was the same as above. Solutions of deoxyHb (60 $\mu \mathrm{M}$ in heme) were generated in $50 \mathrm{mM}$ phosphate buffer (containing $0.2 \mathrm{M}$ in $\mathrm{NaClO}_{4}$ as a frequency and intensity standard) at $\mathrm{pH} 7.4$ by irradiating a solution of $\mathrm{HbCO}$ with visible light at $4{ }^{\circ} \mathrm{C}$ under flowing ultra-pure $\mathrm{N}_{2}$. The fraction of dimeric $\mathrm{Hb}$ is negligible at this concentration for deoxy $\mathrm{Hb} . \underline{30}$ About 0.4

Biochemistry, Vol 48, No. 14 (April 14, 2009): pg. 3120-3126. DOI. This article is (c) American Chemical Society and permission has been granted for this version to appear in e-Publications@Marquette. American Chemical Society does not grant permission for this article to be further copied/distributed or hosted elsewhere without the express permission from American Chemical Society. 
$\mathrm{ml}$ of solution was transferred to an NMR tube under $\mathrm{N}_{2}$ and the $\mathrm{N}_{2}$ atmosphere was maintained during the RR spectral measurements.

Owing to the limited narrow spectral band pass $\left(220 \mathrm{~cm}^{-1}\right)$, the $\mathrm{v}_{4}$ heme band and the $\mathrm{ClO}_{4}{ }^{-}$reference band were measured in separate experiments without altering conditions. Identical results were obtained from three repeated measurement. These measurements were followed immediately by measuring the $\mathrm{HbCO}$ spectrum (CO atmosphere) under identical conditions, because the higher $\mathrm{HbCO}$ concentration $(0.25 \mathrm{mM}$ in heme) required to minimize the dimer dissociation, and lower laser power $(0.3 \mathrm{~mW})$ to minimize $\mathrm{CO}$ photodissociation, precluded the use of $0.2 \mathrm{M}$ in $\mathrm{NaClO}_{4}$ as the intensity standard owing to its very weak signal. The RR cross section of $\mathrm{HbCO}$ was calculated relative to deoxyHb from their relative spectral intensities. The RR cross section was obtained using the following equation $\underline{31}$

$$
\sigma_{\text {sample }}=\sigma_{\text {std }} \times\left(\frac{I_{\text {sample }}}{I_{\text {std }}}\right) \times\left(\frac{C_{\text {std }}}{C_{\text {sample }}}\right) \times\left(\frac{\varepsilon_{\text {sample }}+\varepsilon_{0}}{\varepsilon_{\text {std }}+\varepsilon_{0}}\right)
$$

where $\sigma$ is the RR cross section, I is the intensity, $C$ is the molar concentration and $\varepsilon_{0}, \varepsilon_{\text {sample }}$ and $\varepsilon_{\text {std }}$ are the molar extinction coefficients (in $\mathrm{M}^{-1} \mathrm{~cm}^{-1}$ ) of the sample at the laser excitation wavelength $\left(\varepsilon_{0}\right)$ and at the Raman scattered wavelengths of the sample $\left(\varepsilon_{\text {sample }}\right)$ and internal standard $\left(\varepsilon_{\text {std }}\right)$, respectively.

The spectral data were processed with Grams/AI (7.0) software (Thermo Galactic). The HbCO spectra were deconvoluted using two Lorentzian bands, one for the CO bound form having a fixed bandwidth $\left(8.6 \mathrm{~cm}^{-1}\right)$ and one for the photoproduct whose bandwidth was optimized. (It was not possible to use fixed bandwidth for the photoproduct, since as discussed below, the $\mathrm{v}_{4}$ band of the a subunits shifts to higher frequency during the conformational change from the $R$ to $T$ state, resulting in band broadening in the composite traces.) In the case of the hybrids, the isotope splitting gives four resolved bands, permitting the use of four Lorentzian, two for the $\mathrm{CO}$ bound forms, both having a fixed bandwidth $\left(8.6 \mathrm{~cm}^{-1}\right)$, and two for the deoxy components of the photoproducts, both having a fixed bandwidth $\left(11.2 \mathrm{~cm}^{-1}\right)$. Band areas were used to calculate the RR cross sections.

Biochemistry, Vol 48, No. 14 (April 14, 2009): pg. 3120-3126. DOI. This article is (c) American Chemical Society and permission has been granted for this version to appear in e-Publications@Marquette. American Chemical Society does not grant permission for this article to be further copied/distributed or hosted elsewhere without the express permission from American Chemical Society. 
NOT THE PUBLISHED VERSION; this is the author's final, peer-reviewed manuscript. The published version may be accessed by following the link in the citation at the bottom of the page.

\section{Results}

The $\mathrm{V}_{4} \mathrm{RR}$ band, arising from a breathing mode of the porphyrin ring, is the most prominent peak in RR spectra excited in resonance with the heme Soret absorption band, seen near $400 \mathrm{~nm} \cdot \frac{32,33}{\mathrm{It}}$ is responsive to electron density in the porphyrin ring, and shifts up strongly when $\mathrm{CO}$ binds to deoxyHb (Figure 1 ), as electron density shifts from the ring to the $\mathrm{CO}$ ligand through back-donation of Fe electrons. This frequency separation permits documentation of the $\mathrm{HbCO}$ ligand saturation from measured peak intensities. $\frac{34-36}{3 n}$ addition, $\mathrm{v}_{4}$ shifts down upon ${ }^{15} \mathrm{~N}$ substitution at the pyrrole $\mathrm{N}$ atoms; e.g., by $7 \mathrm{~cm}^{-1}$ in Ni-octaethyl porphyrin. $\frac{37}{A}$ similar shift in $\mathrm{Hb}$, allows for chain-selective resolution of $\mathrm{v}_{4}$, as seen in Figure 1 . The peak heights reveal unequal cross-sections of the chains, higher and lower for a than $\beta$ chains in the deoxy-and CO-forms, respectively (Table 1). $\stackrel{38,39}{ }$ These differences must arise from unequal resonance enhancements, perhaps stemming from slight differences in the Soret electronic bands of the two chains. $\frac{13}{}$

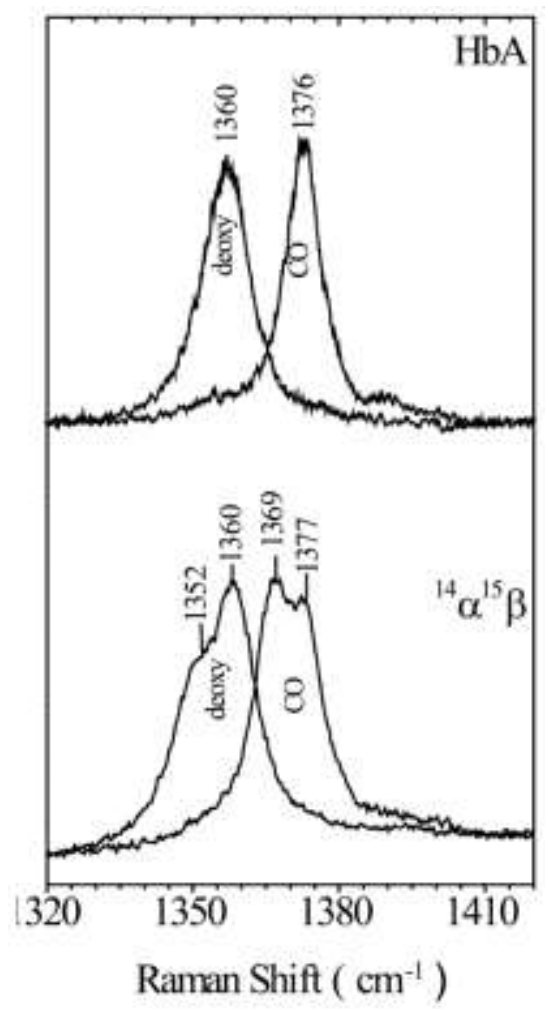

Figure 1. Static RR spectra excited at $426 \mathrm{~nm}(0.3 \mathrm{~mW})$ for the deoxy and COadducts of $\mathrm{HbA}$ and of the $\left({ }^{14} \mathrm{a}^{15} \beta\right)_{2}$ isotope hybrid.

Biochemistry, Vol 48, No. 14 (April 14, 2009): pg. 3120-3126. DOI. This article is (C) American Chemical Society and permission has been granted for this version to appear in e-Publications@Marquette. American Chemical Society does not grant permission for this article to be further copied/distributed or hosted elsewhere without the express permission from American Chemical Society. 
NOT THE PUBLISHED VERSION; this is the author's final, peer-reviewed manuscript. The published version may be accessed by following the link in the citation at the bottom of the page.

Table 1 . The RR cross sections* for the $\mathrm{v}_{4}$ bands of $\mathrm{HbA}$ and of the ${ }^{14} a^{15} \beta$ hybrid

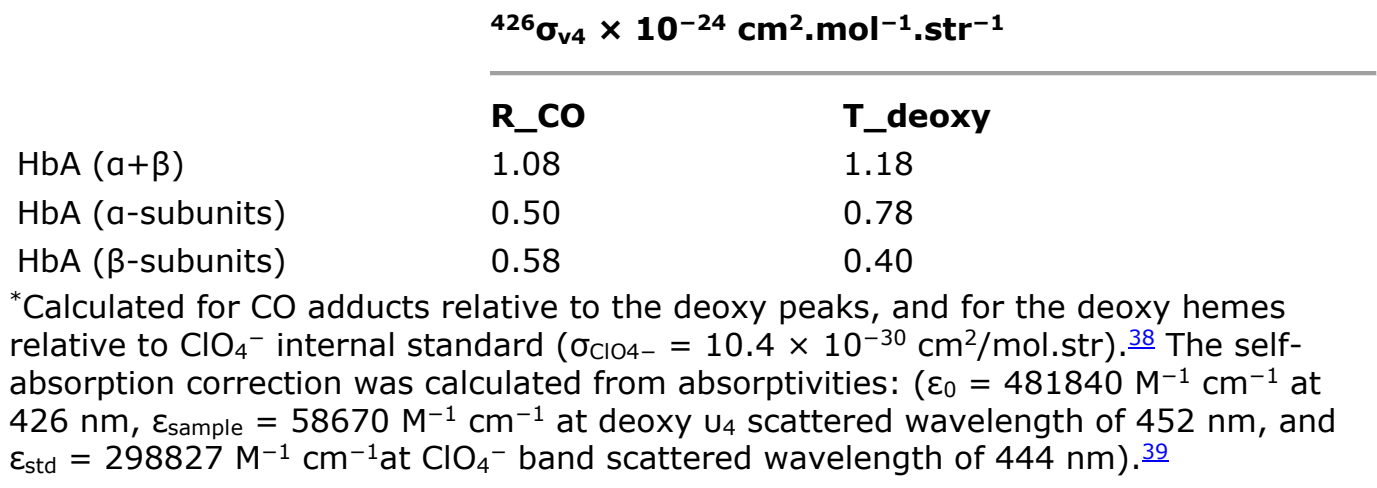

Figure 2 shows time-resolved RR spectra in the $\mathrm{v}_{4}$ region following a saturating photolysis pulse. Due to geminate recombination, a substantial $\mathrm{HbCO}$ peak is seen, even at the earliest time delay, and this peak grows at the expense of the deoxyHb peak at later times, reflecting bimolecular recombination. The bound $\mathrm{CO}$ fraction was determined at each delay, by deconvoluting the peaks and dividing their heights by those obtained from a probe-only spectrum (in order to compensate for the measurable photolysis induced by the probe pulse). $\underline{34-\underline{36}}$ The resulting progress curves (Figure 3) follow an initial rise to a plateau, representing the geminate yield, and a subsequent rise toward full saturation, due to recombination of $\mathrm{CO}$ from solution. The solid curves were constructed with the aid of previously determined $\underline{40}$ time constants for geminate recombination $\left(\mathrm{T}_{\mathrm{gem}}=0.07 \mu \mathrm{s}\right)$ and for bimolecular recombination to the $\mathrm{R}$ and $\mathrm{T}$ states of $\mathrm{Hb}\left(\mathrm{T}_{4}, \mathrm{~T}_{5}=250\right.$ and $1500 \mu \mathrm{s}$ at $\left.1 \mathrm{~atm} \mathrm{CO}\right)$.

Biochemistry, Vol 48, No. 14 (April 14, 2009): pg. 3120-3126. DOI. This article is (c) American Chemical Society and permission has been granted for this version to appear in e-Publications@Marquette. American Chemical Society does not grant permission for this article to be further copied/distributed or hosted elsewhere without the express permission from American Chemical Society. 


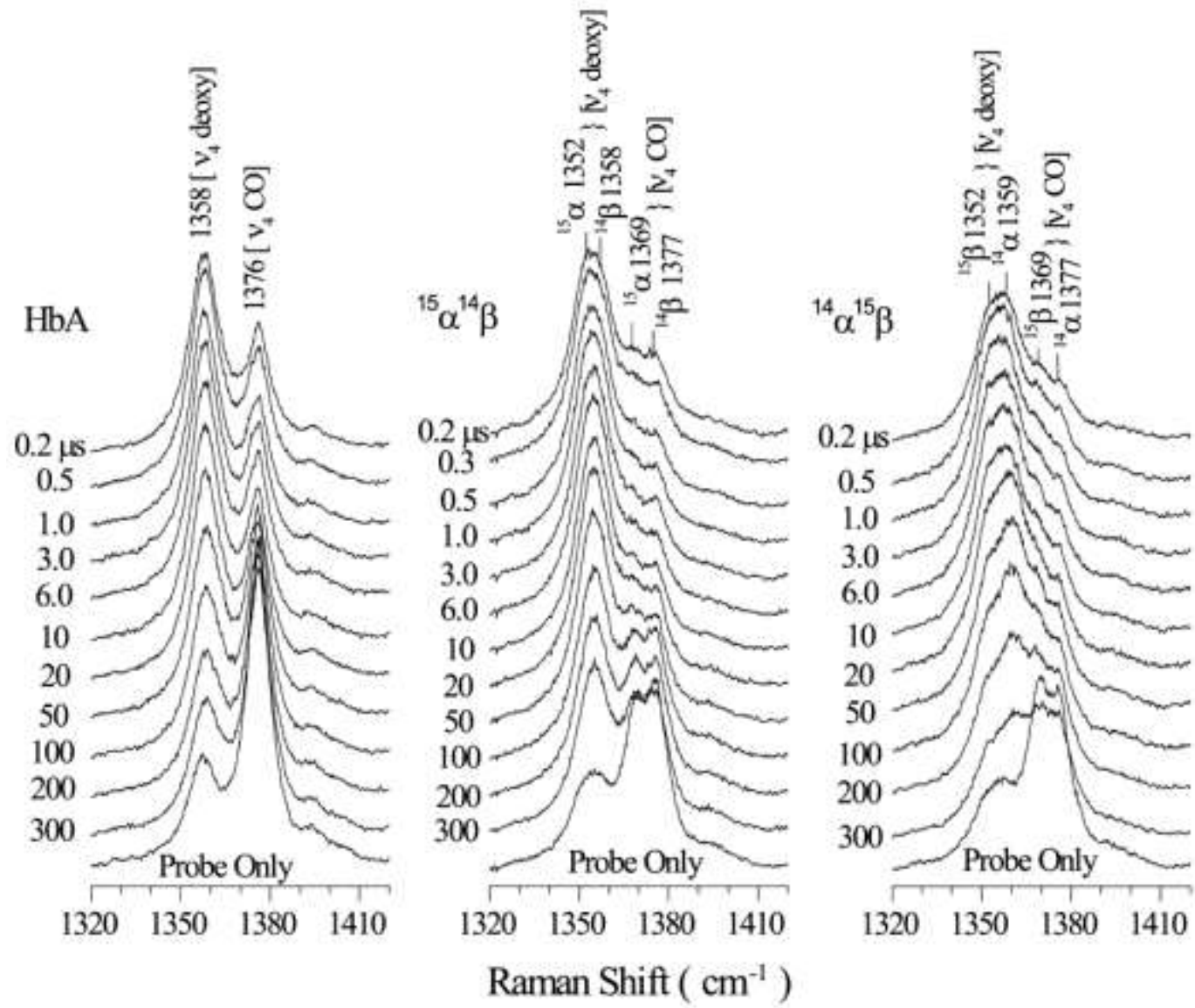

Figure 2. Time-resolved RR spectra at the indicated time ( $\mu \mathrm{s})$ following photolysis of the $\mathrm{CO}$ adduct of $\mathrm{HbA}$ and of the $\left({ }^{15} \mathrm{a}^{14} \beta\right)_{2}$ and $\left({ }^{14} \mathrm{a}{ }^{15} \beta\right)_{2}$ hybrids. Band positions and assignments are marked at the top. Samples were prepared at a heme concentration of $\sim 0.25 \mathrm{mM}$ in CO saturated $50 \mathrm{mM}$ sodium phosphate buffer. $\left[\lambda_{\text {pump }}=419 \mathrm{~nm}, 65\right.$ $\left.\mathrm{mW}, \sim 20 \mathrm{~ns}, 1 \mathrm{kHz} ; \lambda_{\text {probe }}=426 \mathrm{~nm}, 0.5 \mathrm{~mW}, \sim 20 \mathrm{~ns}, 1 \mathrm{kHz}\right]$.

Biochemistry, Vol 48, No. 14 (April 14, 2009): pg. 3120-3126. DOI. This article is (c) American Chemical Society and permission has been granted for this version to appear in e-Publications@Marquette. American Chemical Society does not grant permission for this article to be further copied/distributed or hosted elsewhere without the express permission from American Chemical Society. 
NOT THE PUBLISHED VERSION; this is the author's final, peer-reviewed manuscript. The published version may be accessed by following the link in the citation at the bottom of the page.

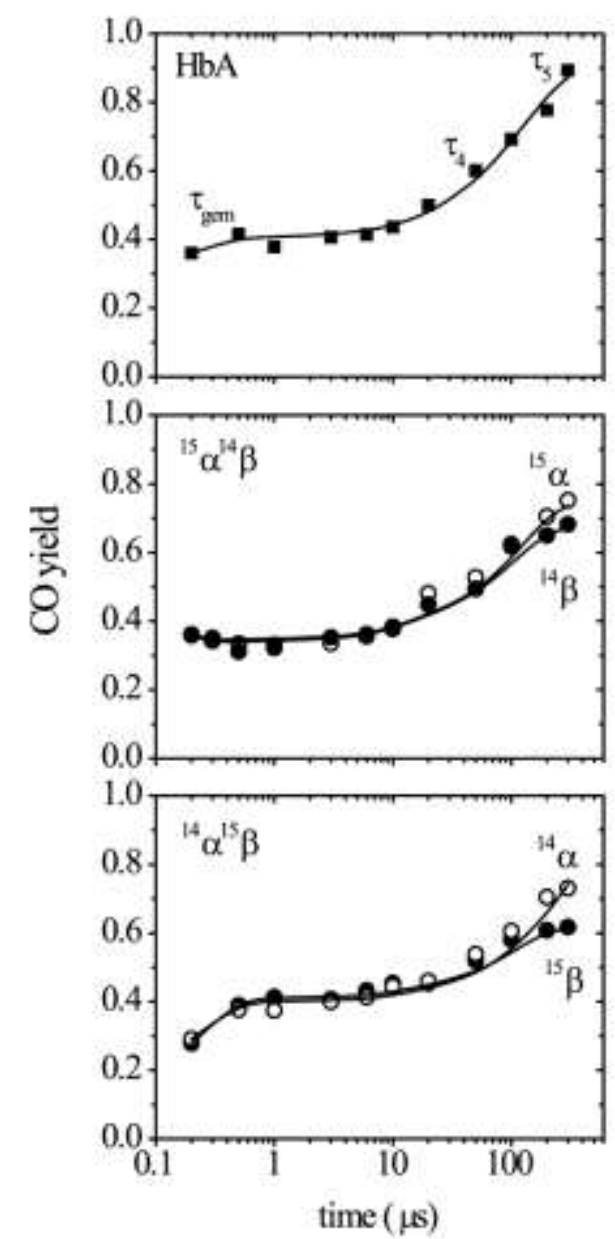

Figure 3. The $\mathrm{CO}$ rebinding to photolyzed $\mathrm{CO}$ adducts of $\mathrm{HbA}$ and the indicated $\mathrm{Hb}$ hybrids, determined from the intensity of the $\mathrm{v}_{4} \mathrm{CO}$-heme band. The continuous lines correspond to modeling of the $\mathrm{CO}$ recombination reaction with the time constants, 40 $\mathrm{T}_{\text {gem }}$ (geminate phase), $\mathrm{T}_{4}$ (R-state bimolecular rebinding), and $\mathrm{T}_{5}$ ( $\mathrm{T}$-state bimolecular rebinding).

For the ${ }^{15 / 14} \mathrm{~N}$ hybrids, the $\mathrm{v}_{4}$ envelope was decomposed into individual components via curve resolution. The quality of the curve fitting is illustrated in Figure 4. Essentially the same progress curves were obtained for both hybrids (Figure 3 ), and for native HbA, confirming the validity of the methodology. The important result is that the progress curves are indistinguishable for $a$ and $\beta$ chains, which have the same geminate yield, $0.39+/-0.02$ and similar recombination rates (the curves are too short to be precise about the rates.)

Biochemistry, Vol 48, No. 14 (April 14, 2009): pg. 3120-3126. DOI. This article is (C) American Chemical Society and permission has been granted for this version to appear in e-Publications@Marquette. American Chemical Society does not grant permission for this article to be further copied/distributed or hosted elsewhere without the express permission from American Chemical Society. 

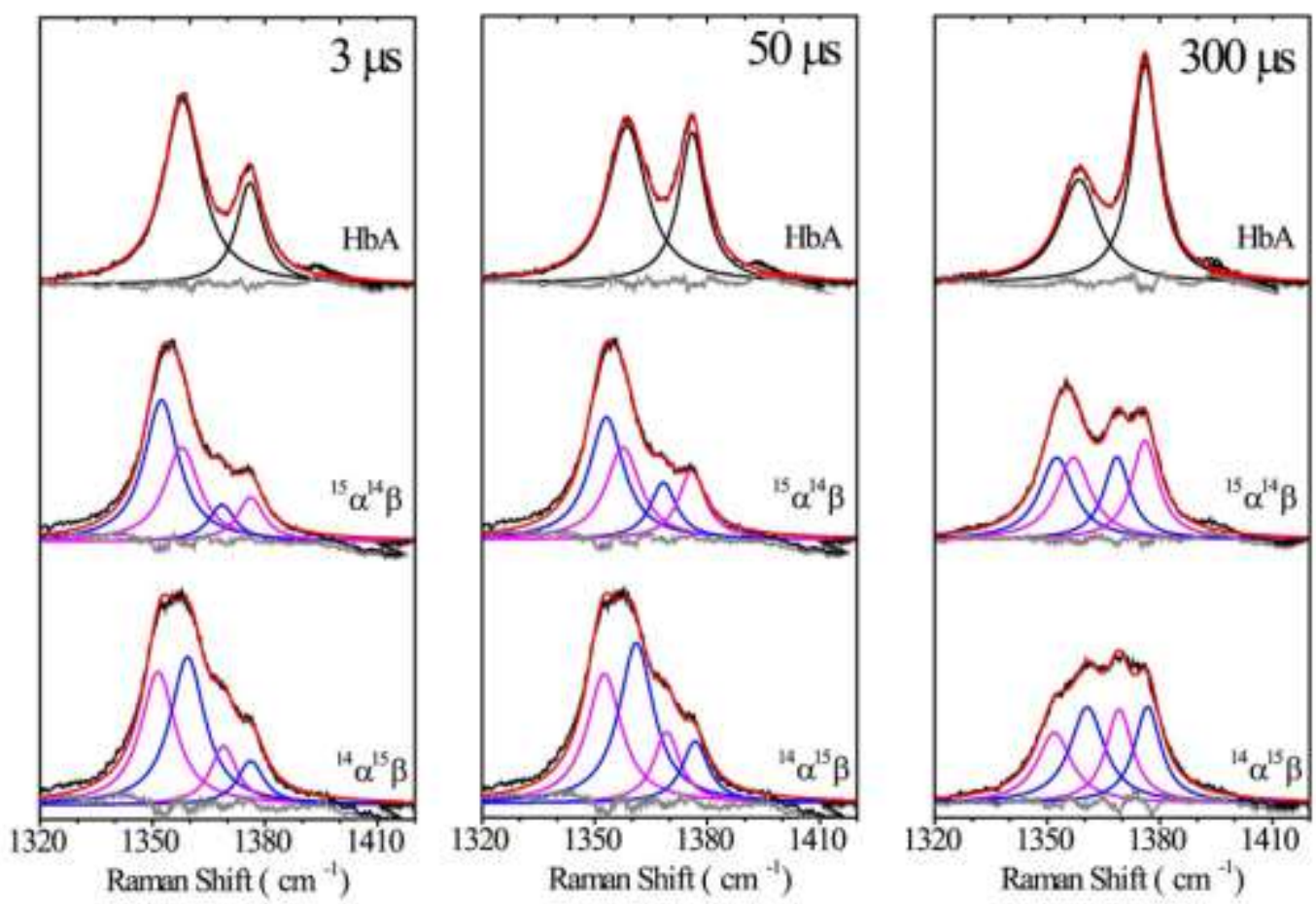

Figure 4. Example of RR band deconvolution at 3, 50 and $300 \mu$ s following $\mathrm{CO}$ photolysis, showing the experimental data (black) fitted spectra (green), deconvoluted deoxy bands (red), CO bands (blue) and the residuals (gray).

However, the two chains do differ in their spectral response. Accurate fitting of the curves required a distinct $v_{4}$ upshift with time for the a but not the $\beta$ chains. As illustrated in Figure 5 , among the four $\mathrm{v}_{4}$ components, only the $\mathrm{a}_{\text {deoxy }}$ peak shifts position with time, whether the chain contains ${ }^{14} \mathrm{~N}$ or ${ }^{15} \mathrm{~N}$ labeled heme. This shift was confirmed by taking difference spectra between early and late times, which revealed a sigmoidal band only for the $a_{\text {deoxy }}$ signal (Fig. S1). The time course for the $a_{d e o x y} v_{4}$ shift is shown in Figure 6 , which also shows that the corresponding shift for unlabeled deoxyHb is half that of the $a_{\text {deoxy }}$ peak, consistent with the $\mathrm{HbA}$ signal being a composite of the shifted a peak and the unshifted $\beta$ peak. The solid curves are drawn to conform to the time constants determined via time-resolved UVRR spectroscopy 34 for signals associated with changes in protein structure. Most of the $a_{\text {deoxy }} v_{4}$ shift is associated with $T_{2}(2 \mu s)$ and $\mathrm{T}_{3}(20 \mu \mathrm{s})$, the protein motions, which involve formation of the $\mathrm{T}$ state contacts. $\frac{34}{3}$

Biochemistry, Vol 48, No. 14 (April 14, 2009): pg. 3120-3126. DOI. This article is (c) American Chemical Society and permission has been granted for this version to appear in e-Publications@Marquette. American Chemical Society does not grant permission for this article to be further copied/distributed or hosted elsewhere without the express permission from American Chemical Society. 
NOT THE PUBLISHED VERSION; this is the author's final, peer-reviewed manuscript. The published version may be accessed by following the link in the citation at the bottom of the page.
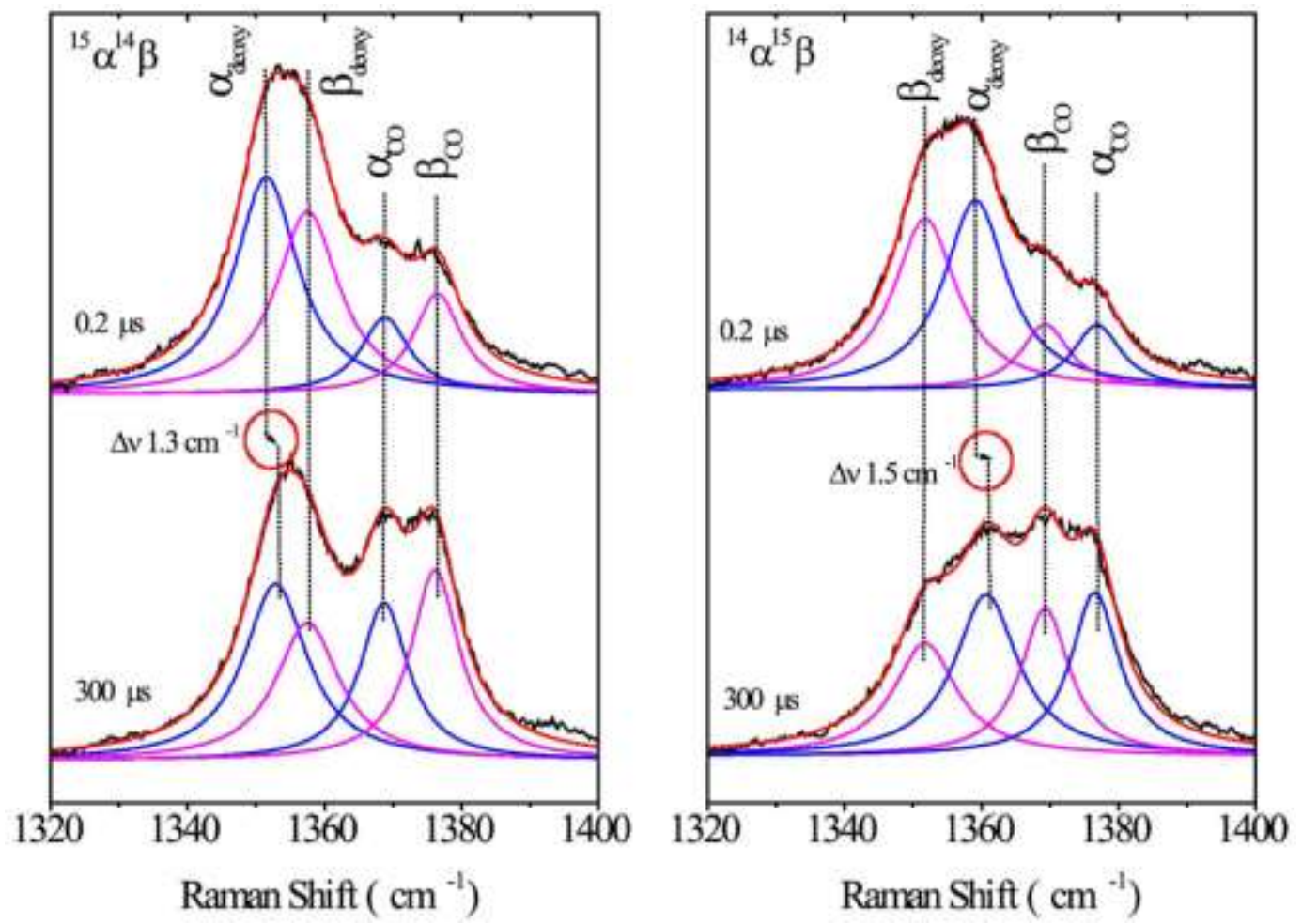

Figure 5. Deconvolution data showing that $\mathrm{v}_{4}$ shift with time only for a- subunits in the deoxy state.

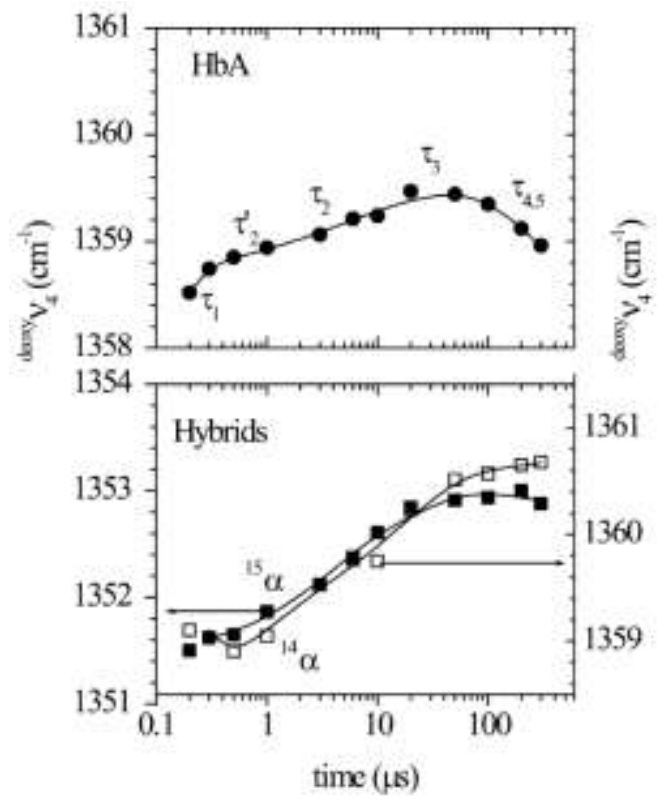

Figure 6. Time evolution (log scale) for the deoxy $\mathrm{v}_{4}$ frequencies of $\mathrm{HbA}$ and for the a- subunits in $\left({ }^{15} a{ }^{14} \beta\right)_{2}$ and $\left({ }^{14} a{ }^{15} \beta\right)_{2}$ hybrids, following CO-photolysis. The continuous lines correspond to modeling with a series of time constants ( $T_{1}=65 \mathrm{~ns}$; $\mathrm{T}_{2}{ }^{\prime}=0.74 \mu \mathrm{s} ; \mathrm{T}_{2}=2.9 \mu \mathrm{s} ; \mathrm{T}_{3}=20.5 \mu \mathrm{s} ; \mathrm{T}_{4,5}=497 \mu \mathrm{s}$ ) previously documented for protein structural changes from UVRR spectroscopy. $\underline{34}$

Biochemistry, Vol 48, No. 14 (April 14, 2009): pg. 3120-3126. DOI. This article is (c) American Chemical Society and permission has been granted for this version to appear in e-Publications@Marquette. American Chemical Society does not grant permission for this article to be further copied/distributed or hosted elsewhere without the express permission from American Chemical Society. 
NOT THE PUBLISHED VERSION; this is the author's final, peer-reviewed manuscript. The published version may be accessed by following the link in the citation at the bottom of the page.

\section{Discussion}

The present results confirm a distinct structural difference between the two chains in the deoxy forms. We find that the $v_{4}$ frequency shifts up with time in the a but not in the $\beta$ chains. The largest changes (Figure 6) occur at $\sim 2 \mu$ s and $20 \mu$ s after CO photodissociation, phases known from UVRR studies $\frac{34}{4}$ to be associated with formation of the T state contacts at the 'hinge' and 'switch' regions of the $a_{1} \beta_{2}$ interface.

The position of $\mathrm{v}_{4}$ is known to correlate negatively with the stretching frequency, $\mathrm{v}_{\mathrm{Fe}-\mathrm{His}}$, of the bond between the heme Fe and the proximal histidine ligand, for a variety of deoxyHb constructs. ${ }^{41} \mathrm{~A}$ depressed $\mathrm{V}_{\mathrm{Fe}}$-His is observed in the $\mathrm{Hb}$ T-state $\left(216 \mathrm{~cm}^{-1}\right.$ vs $222 \mathrm{~cm}^{-1}$ in deoxymyoglobin or in relaxed forms of deoxyHb) $)^{42,43}$ and is the most direct evidence for tension at the proximal Fe-His connection, underlying the constraint to ligand binding that triggers the $T-R$ transition in Perutz' stereochemical mechanism. ${ }^{4}$ Moreover the evolution of $\mathrm{V}_{\mathrm{Fe} \text {-His }}$ after $\mathrm{HbCO}$ photolysis was previously shown to track T state formation. ${ }^{44}$ Earlier RR studies of hybrid Hb's have shown that this tension is expressed in the a chains and the present results confirm that the tension develops in concert with the R-T conversion.

However, this tension is not manifest in the $\beta$ chains. The $\beta_{\text {deoxy }}$ $v_{4}$ does not evolve in time, and the metal hybrid data indicate little change in $\mathrm{V}_{\mathrm{Fe}}$-His between $\mathrm{R}$ and $\mathrm{T}$ states for the deoxy- $\beta$-chains. $\underline{45}$

Immediately after photolysis, neither chain is under tension, and the present results show them to be functionally equivalent. The CO rebinding rates and geminate yields are indistinguishable (Figure 3 ). UVRR studies have shown CO rebinding to be concurrent with the first concerted protein motion after photolysis 34,36 which is detected as a loss of tertiary $\mathrm{H}$-bond contacts, and interpreted as a rotation of the $\mathrm{E}$ and $\mathrm{F}$ helices that hold the heme like a clamshell(Figure 7). Displacement of the $E$ helix toward the heme was suggested to impel the photodissociated $\mathrm{CO}$ to either rebind or to exit the heme pocket. 34,36 


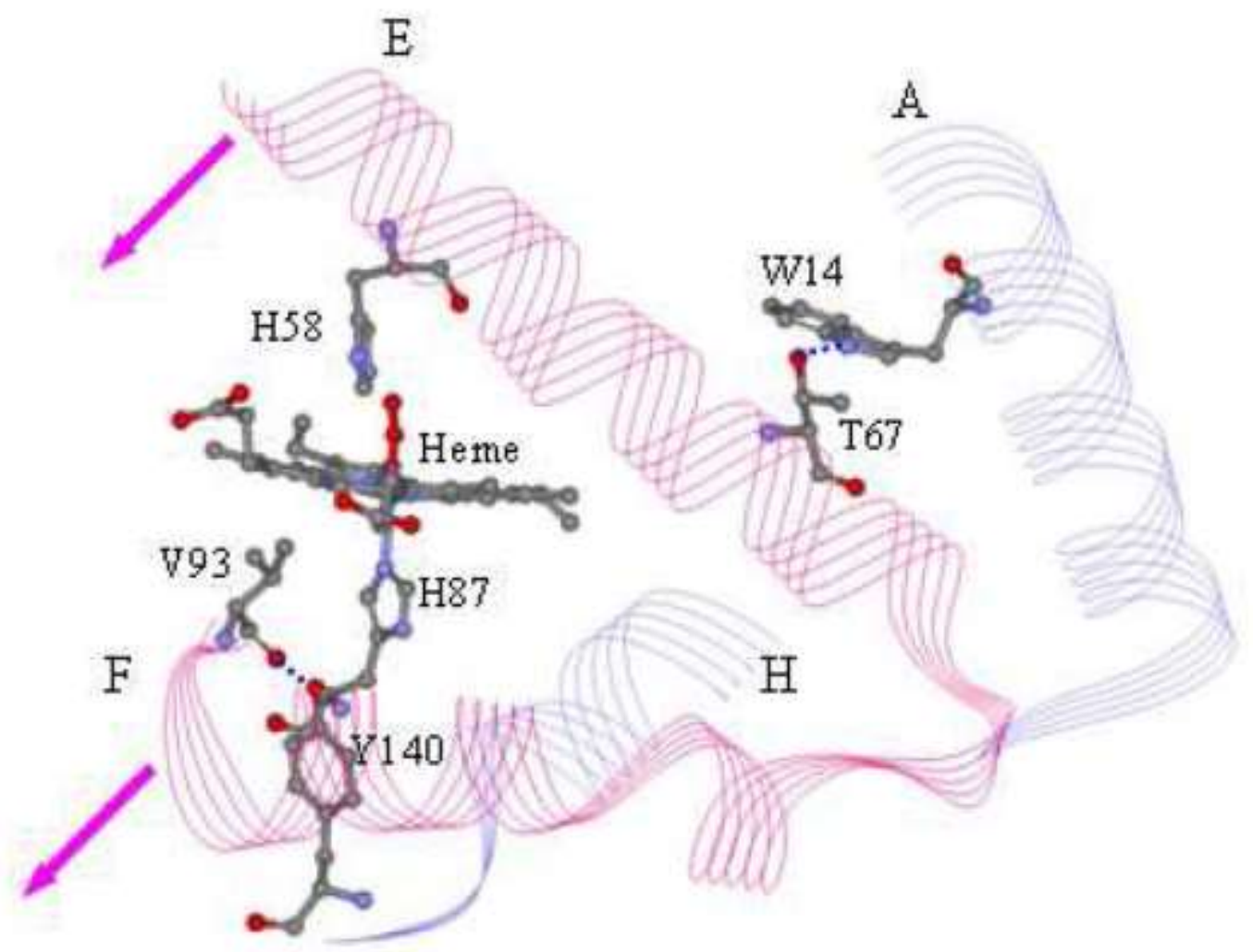

Figure 7. Diagram of the EF clamshell rotation proposed 34,36 to follow $\mathrm{HbCO}$ photodissociation. Displacement of the high-spin Fe from the heme plane impels the $F$ helix away from the heme, while E helix movement toward the heme expels $\mathrm{CO}$ from the heme pocket or else induces geminate recombination.

This mechanism is presumed to be the same for both chains. Nevertheless it is surprising that the branching ratio between $\mathrm{CO}$ exit and rebinding is exactly the same.

One possibility is that mechanical coupling across the $a_{1} \beta_{1}$ dimer interface ensures equivalent functionality. In other words, rebinding to one half of an $a \beta$ dimer induces a structural change that is propagated to the other half, requiring equivalent rebinding at the opposite heme; the dimer then acts as a single dynamical unit. This hypothesis is supported by UVRR results showing equivalent changes in the protein dynamics when one of the anchoring inter-helical $\mathrm{H}$-bonds is abolished in one chain or another, or in both. $\underline{46}$ Moreover, transmission of distal interactions across the $a_{1} \beta_{1}$ interface was earlier demonstrated by Levy et al.,,$\underline{47}$ who found distinctive differences in the ligation of the distal histidine to Fe(III)-heme in valency hybrid Hbs, depending on whether ligated subunits were in the same dimer (symmetric hybrids) or in the

Biochemistry, Vol 48, No. 14 (April 14, 2009): pg. 3120-3126. DOI. This article is (C) American Chemical Society and permission has been granted for this version to appear in e-Publications@Marquette. American Chemical Society does not grant permission for this article to be further copied/distributed or hosted elsewhere without the express permission from American Chemical Society. 
opposite dimer (asymmetric hybrids). Molecular dynamics simulation of an a $\beta$ dimer revealed spontaneous formation of a $\mathrm{Fe}$ (III)-distal histidine bond in the a subunit; this did not occur if the interface was frozen in the simulation, nor did it occur in isolated subunits. $\underline{48}$

Intra-dimer cooperativity in the T-state has long been propounded by Ackers and coworkers, $\underline{49}$ based on extensive measurements of dimer assembly free energies. Analysis of several hybrid Hb's revealed greater stability of doubly ligated tetramers when the two ligands are on the same dimer than when they are on opposite dimers. There has been controversy about the extent of the intradimer cooperativity, based on error analysis of different methodologies, $\underline{50}, \underline{51}$ but the basic phenomenon seems well established. $\underline{50}$

The other possibility is that the $\alpha / \beta$ equivalence is intrinsic to the chains, and arises from evolutionary pressure to endow structurally inequivalent chains with the same functional properties. $\mathrm{QM} / \mathrm{MM}$ computations indicate equal contribution to the R-T energy difference from structural change in the two chains. $\frac{5}{}$ There is, of course, selective pressure for such a development, since deviations from binding equivalence reduce cooperativity, and therefore physiological efficiency, in the Hb tetramer. $\underline{6}$ A variety of measurements have produced evidence for near-equivalence of the chains both in the R-state as well as in the T-state. Thus Bettati et al., estimated the T-state $\mathrm{O}_{2}$ affinities of $\mathrm{a}$ and $\beta$ chains to differ by less than a factor of 3 from polarized spectral measurements of deoxyHb single crystals. $\underline{52}$ The most comprehensive study of chain differences was carried out by Unzai et al., $\underline{6}$ who analyzed $\mathrm{CO}$ and $\mathrm{O}_{2}$ binding for hybrid Hb's in which one of the chains contained $\mathrm{Mg}$ (II) or $\mathrm{Ni}$ (II), which stabilize the $\mathrm{T}$ state, or $\mathrm{Cr}$ (III) and $\mathrm{Mn}$ (III), which stabilize the $\mathrm{R}$ state. They found similar affinities and binding rates for both chains in both states. There were up to 2-fold chain differences in $\mathrm{CO}$ and $\mathrm{O}_{2}$ association and dissociation rates for $\mathrm{R}$-state $\mathrm{Hb}$ and for $\mathrm{CO}$ association rates in the T-state ( $\mathrm{CO}$ dissociation proved hard to measure); for $\mathrm{O}_{2}$ the $\mathrm{T}$-state association and dissociation rates were essentially the same for the two chains. While intra-dimer coupling could explain $a / \beta$ functional equivalence in native $\mathrm{Hb}$, it cannot do so for metal (symmetric) hybrids, since in that case either the a or $\beta$ chains are non-functional in ligand binding.

Biochemistry, Vol 48, No. 14 (April 14, 2009): pg. 3120-3126. DOI. This article is (C) American Chemical Society and permission has been granted for this version to appear in e-Publications@Marquette. American Chemical Society does not grant permission for this article to be further copied/distributed or hosted elsewhere without the express permission from American Chemical Society. 
The most relevant comparison of our results is with the rebinding measurements on Co/Fe hybrids by Hofrichter et al., 13 who found $\mathrm{CO}$ geminate rebinding times of 76 and 53 ns and geminate yields of 0.35 and 0.22 for $\beta$ and a chains, respectively. The geminate yield is critical to the present argument since it is sensitive to steric factors in the heme pocket, which control the probability of rebinding vs escape. 4,53 These factors are different in the two chains. The $\beta$ pocket is more crowded than the a pocket, and this crowding might be expected to increase the rebinding probability. The $50 \%$ higher geminate yield of $\beta$ than of a chains measured by Hofrichter et al. $\underline{13}$ is consistent with this difference. However, Samuni et al., have reported that the dissociated $\mathrm{CO}$ rapidly escapes into adjacent cavity in $\beta$ subunits of the $a(Z n) \beta(F e C O)$ hybrid in the T-state and thus offsets the crowding effect, possibly favoring a higher geminate yield. $\underline{54}$ In an event, the lower a yield was attributed by Hofrichter et al. $\underline{13}$ to a fraction of the molecules being in the T-state is, in which the geminate yield is known to be lowered. A variety of evidence supports the inference that the $\mathrm{T}$-state is favored in a-Fe-containing, but not the $\beta$ Fe-containing Co/Fe hybrid. $\underline{13}$ Thus it remains possible, though surprising, that the indistinguishability of the a and $\beta$ geminate yields in native $\mathrm{Hb}$ is entirely ascribable to convergent evolution of the chains.

\section{Conclusions}

A variety of observations point to similar ligand affinities and binding rates in the two chains of $\mathrm{Hb}$, despite well-characterized structural differences. $\underline{6}$ This similarity can be viewed as the evolution of similar function by different intra-chain mechanisms, driven by the requirement of high binding cooperativity for physiological efficiency of $\mathrm{O}_{2}$ delivery by tetrameric $\mathrm{Hb}$. However, the present results, in which rebinding is monitored for individual chains within native $\mathrm{Hb}$, reveal identical $a$ and $\beta$ geminate yields, although a higher $\beta$ geminate yield is expected for the more crowded $\beta$ chains. ${ }^{4}$ A possible mechanism for abolition of chain differences is mechanical coupling that assures equivalent binding in both halves of an $a \beta$ dimer. $A$ higher $\beta$ than $a$ geminate yield has been reported for $\mathrm{Co} /$ Fe hybrids, $\underline{13}$ in which intradimer coupling would not be operative. However, this difference could be attributed to a population of T-state molecules in the a-Fe hybrid.

Biochemistry, Vol 48, No. 14 (April 14, 2009): pg. 3120-3126. DOI. This article is (c) American Chemical Society and permission has been granted for this version to appear in e-Publications@Marquette. American Chemical Society does not grant permission for this article to be further copied/distributed or hosted elsewhere without the express permission from American Chemical Society. 
Thus, while the present results firmly document equivalency in geminate rebinding, the precise mechanism for suppressing chain inequivalence remains an open issue.

\section{Abbreviations}

$\begin{array}{ll}\text { RR } & \text { resonance Raman } \\ \text { UVRR } & \text { ultraviolet resonance Raman } \\ \text { TR3 } & \text { time-resolved resonance Raman } \\ \text { TLC } & \text { thin-layer chromatography } \\ \mathrm{HbCO} & \text { carbonmonoxy hemoglobin } \\ \mathrm{Hbdoexy} & \text { deligated hemoglobin } \\ { }^{15} \mathrm{~N}-\mathrm{Fe}{ }^{\mathrm{III}}(\mathrm{PPIX}) \mathrm{Cl} & { }^{15} \mathrm{~N} \text {-ferriprotoporphyrin IX chloride } \\ \mathrm{PMB} & \text { sodium p-(hydroxymercuri)benzoate } \\ \mathrm{a}_{\mathrm{N} 15} \mathrm{CO}, \mathrm{a}_{\mathrm{N} 14} \mathrm{CO}, \beta_{\mathrm{N} 15}{ }^{\mathrm{CO}}, & \text { a- or } \beta \text {-subunits containing CO bound heme with }{ }^{14} \mathrm{~N} \text { or } \\ \text { or } \beta_{\mathrm{N} 14}{ }^{\mathrm{CO}} & { }^{15} \mathrm{~N} \text { isotopes at the pyrrole ring. }\end{array}$

\section{Footnotes}

This work was supported by NIH Grant GM 12526 (to TGS) and DK35153 (to JRK).

\section{References}

${ }^{1}$ Perutz MF. Mechanisms of Cooperativity and Allosteric Regulation in Proteins. Cambridge: Cambridge University Press; 1990.

2 Baldwin J, Chothia C. Hemoglobin - Structural-Changes Related to LigandBinding and Its Allosteric Mechanism. J. Mol. Biol. 1979;129 175-\&.

3 Monod J, Wyman J, Changeux JP. On nature of allosteric transitions-A plausible model. J. Mol. Biol. 1965;12 88-\&.

${ }^{4}$ Perutz MF. Stereochemistry of cooperative effects in haemoglobin. Nature. $1970 ; 228726-\&$.

${ }^{5}$ Alcantara RE, Xu C, Spiro TG, Guallar V. A quantum-chemical picture of hemoglobin affinity. Proc. Nat. Acad. Sci. USA. 2007;104:1845118455.

${ }^{6}$ Unzai S, Eich R, Shibayama N, Olson JS, Morimoto H. Rate constants for O-2 and $\mathrm{CO}$ binding to the alpha and beta subunits within the $\mathrm{R}$ and $\mathrm{T}$ states of human hemoglobin. J. Biol. Chem. 1998;273:23150-23159.

7 Brunori M, Amiconi G, Antonini E, Wyman J, Winterha Kh. Artificial intermediates in reaction of haemoglobin - functional and

Biochemistry, Vol 48, No. 14 (April 14, 2009): pg. 3120-3126. DOI. This article is (C) American Chemical Society and permission has been granted for this version to appear in e-Publications@Marquette. American Chemical Society does not grant permission for this article to be further copied/distributed or hosted elsewhere without the express permission from American Chemical Society. 
conformational properties of cyanmet intermediates. J. Mol. Biol. 1970;49 461-\&.

${ }^{8}$ Cassoly R, Gibson QH. Kinetics of ligand binding to hemoglobin valency hybrids and effect of anions. J. Biol. Chem. 1972;247 7332-\&.

${ }^{9}$ Hoffman BM, Gibson QH, Bull C, Crepeau RH, Edelstein SJ, Fisher RG, McDonald MJ. Manganese-substituted hemoglobin and myoglobin. Ann. N.Y. Acad. Sci. 1975;244:174-186.

${ }^{10}$ Ikedasaito M, Yonetani T. Studies on cobalt myoglobins and hemoglobins .11. The interaction of carbon-monoxide and oxygen with alpha-subunits and beta-subunits in iron-cobalt hybrid hemoglobins. J. Mol. Biol. 1980;138:845-858.

${ }^{11}$ Blough NV, Hoffman BM. Equilibrium and Kinetic CO Binding Parameters of T-State And R-State Hemoglobin Chains Using Iron-Manganese Hybrids. J. Am. Chem. Soc. 1982;104:4247-4250.

12 Blough NV, Hoffman BM. Carbon-monoxide binding to the ferrous chains of $[\mathrm{mn}, \mathrm{fe}(\mathrm{ii})]$ hybrid hemoglobins-pH-dependence of the chain affinity constants associated with specific hemoglobin ligation pathways. Biochemistry. 1984;23:2875-2882.

13 Hofrichter J, Henry ER, Sommer JH, Deutsch R, Ikedasaito M, Yonetani T, Eaton WA. Nanosecond optical-spectra of iron cobalt hybrid hemoglobins - geminate recombination, conformational-changes, and intersubunit communication. Biochemistry. 1985;24:2667-2679.

${ }^{14}$ Shibayama N, Yonetani T, Regan RM, Gibson QH. Mechanism of ligandbinding to ni(ii)-fe(ii) hybrid hemoglobins. Biochemistry. 1995;34:14658-14667.

15 Philo JS, Dreyer U, Lary JW. Quaternary structure dynamics and carbon monoxide binding kinetics of hemoglobin valency hybrids. Biophys. J. 1996;70:1949-1965.

16 Unzai S, Hori H, Miyazaki G, Shibayama N, Morimoto H. Oxygen equilibrium properties of chromium(III)-iron(II) hybrid hemoglobins. J. Biol. Chem. 1996;271:12451-12456.

17 Ackers GK, Doyle ML, Myers D, Daugherty MA. Molecular code for cooperativity in hemoglobin. Science. 1992;255:54-63.

18 Mathews AJ, Olson JS. Assignment of rate constants for $\mathrm{O}-2$ and $\mathrm{CO}$ binding to alpha-subunit and beta-subunit within R-state and T-state human hemoglobin. Hemoglobins, Pt C. 1994:363-386.

19 Mathews AJ, Olson JS. Assignment of rate constants for O-2 and CO binding to alpha-subunit and beta-subunit within R-state and T-state human hemoglobin. Methods Enzymol. 1994;232:363.

${ }^{20}$ Fuhrhop JH, Smith KM, editors. North Holland, Amsterdam: Elsevier Publishing Co.; 1975. Laboratory methods in porphyrin and metalloporphyrin research.

Biochemistry, Vol 48, No. 14 (April 14, 2009): pg. 3120-3126. DOI. This article is (c) American Chemical Society and permission has been granted for this version to appear in e-Publications@Marquette. American Chemical Society does not grant permission for this article to be further copied/distributed or hosted elsewhere without the express permission from American Chemical Society. 
${ }^{21}$ DiNello RK, Chang CK. Isolation and modification of natural porphyrins. In: Dolphin D, editor. The Porphyrins. Structure and synthesis. New York: Academic Press; 1978. pp. 289-339.

22 Janson TR, Katz JJ. Nuclear magnetic resonance spectroscopy of diamgnetic porphyrins, in The Porphyrins. In: Dolphin D, editor. Physical chemistry. New York: Academic Press; 1979. pp. 1-59.

23 Riggs A. Preparation of blood hemoglobins of vertebrates. Methods Enzymol. 1981;76:5-29.

24 Yip YK, Waks M, Beychok S. Influence of prosthetic groups on protein folding and subunit assembly .1. Conformational differences between separated human alpha-globins and beta-globins. J. Biol. Chem. 1972;247 7237-\&.

25 Jeyarajah S, Kincaid JR. Resonance raman studies of hemoglobins reconstituted with mesoheme-unperturbed iron histidine stretching frequencies in a functionally altered hemoglobin. Biochemistry. 1990;29:5087-5094.

${ }^{26}$ Smith KM, Parish DW, Inouye WS. Methyl deuteration reactions in vinylporphyrins-protoporphyrins IX, III, AND XIII. J. Org. Chem. 1986;51:666-671.

27 Yip YK, Waks M, Beychok S. Reconstitution of native human hemoglobin from separated globin chains and alloplex intermediates. Proc. Nat. Acad. Sci. USA. 1977;74:64-68.

${ }^{28}$ Zhao XJ, Chen RP, Tengroth C, Spiro TG. Solid-state tunable kHz ultraviolet laser for Raman applications. Appl. Spectrosc. 1999;53:1200-1205.

${ }^{29}$ Zhao XJ, Tengroth C, Chen RP, Simpson WR, Spiro TG. Time-resolved Raman spectroscopy with a tunable ultraviolet kilohertz nanosecond laser. J. Raman Spectros. 1999;30:773-776.

30 Thomas JO, Edelstei Sj. Observation of dissociation of unliganded hemoglobin .2. Effect of $\mathrm{pH}$, salt, and dioxane. J. Biol. Chem. 1973;248:2901-2905.

${ }^{31}$ Chang S, Yang W, Spiro TG. Saturation Effects on Ultraviolet Resonance Raman Intensities - Excimer/Yag Laser Comparison and Aromatic Amino-Acid Cross-Sections. J. Raman Spectros. 1990;21:435-440.

32 Spiro TG, Li XY. Resonance Raman Spectra of Metalloporphyrins. In: Spiro TG, editor. Biological Application of Raman Spectroscopy. John Wiley \& Sons.; 1987. pp. 1-37.

${ }^{33}$ Spiro TG, Strekas TC. Resonance Raman-spectra of heme proteins-effects of oxidation and spin state. J. Am. Chem. Soc. 1974;96:338-345.

${ }^{34}$ Balakrishnan G, Case MA, Pevsner A, Zhao XJ, Tengroth C, McLendon GL, Spiro TG. Time-resolved absorption and UV resonance Raman spectra reveal stepwise formation of $T$ quaternary contacts in the allosteric pathway of hemoglobin. J. Mol. Biol. 2004;340:843-856.

Biochemistry, Vol 48, No. 14 (April 14, 2009): pg. 3120-3126. DOI. This article is (c) American Chemical Society and permission has been granted for this version to appear in e-Publications@Marquette. American Chemical Society does not grant permission for this article to be further copied/distributed or hosted elsewhere without the express permission from American Chemical Society. 
NOT THE PUBLISHED VERSION; this is the author's final, peer-reviewed manuscript. The published version may be accessed by following the link in the citation at the bottom of the page.

${ }^{35}$ Friedman JM, Lyons KB. Transient raman-study of CO-hemoprotein photolysis-origin of the quantum yield. Nature. 1980;284:570-572.

36 Jayaraman V, Rodgers KR, Mukerji I, Spiro TG. Hemoglobin Allostery Resonance Raman-Spectroscopy of Kinetic Intermediates. Science. 1995;269:1843-1848.

37 Li XY, Czernuszewicz RS, Kincaid JR, Stein P, Spiro TG. Consistent Porphyrin Force-Field .2. Nickel Octaethylporphyrin Skeletal and Substituent Mode Assignments from N-15, Meso-D4, and MethyleneD16 Raman and Infrared Isotope Shifts. J. Phys. Chem. 1990;94:4761.

38 Dudik JM, Johnson CR, Asher SA. Wavelength dependence of the preresonance raman cross-sections of $\mathrm{CH} 3 \mathrm{CN}, \mathrm{SO} 42-, \mathrm{ClO} 4-$, and $\mathrm{NO} 3$. J. Chem. Phys. 1985;82:1732-1740.

${ }^{39}$ http://omlc.ogi.edu/spectra/hemoglobin/summary.html.

${ }^{40} \mathrm{Hu}$ XH, Frei H, Spiro TG. Nanosecond step-scan FTIR spectroscopy of hemoglobin: Ligand recombination and protein conformational changes. Biochemistry. 1996;35:13001-13005.

${ }^{41}$ Ondrias MR, Rousseau DL, Shelnutt JA, Simon SR. Quaternarytransformation-induced changes at the heme in deoxyheoglobins. Biochemistry. 1982;21:3428-3437.

42 Friedman JM, Rousseau DL, Ondrias MR. Time-resolved resonance raman studies of hemoglobin. Annu. Rev. Phys. Chem. 1982;33:471-491.

43 Friedman JM, Rousseau DL, Ondrias MR, Stepnoski RA. Transient ramanstudy of hemoglobin - structural dependence of the iron-histidine linkage. Science. 1982;218:1244-1246.

44 Jayaraman V, Spiro TG. Structural evolution of the heme group during the allosteric transition in hemoglobin: Insights from resonance Raman spectra of isotopically labeled heme. Biospectroscopy. 1996;2:311316.

45 Ondrias MR, Rousseau DL, Kitagawa T, Ikedasaito M, Inubushi T, Yonetani T. Quaternary structure changes in iron-cobalt hybrid hemoglobins detected by resonance raman-scattering. J. Biol. Chem. $1982 ; 257: 8766-8770$.

46 Balakrishnan G, Tsai CH, Wu Q, Case MA, Pevsner A, McLendon GL, Ho C, Spiro TG. Hemoglobin site-mutants reveal dynamical role of interhelical $\mathrm{H}$-bonds in the allosteric pathway: Time-resolved UV resonance Raman evidence for intra-dimer coupling. J. Mol. Biol. 2004;340:857-868.

47 Levy A, Sharma VS, Zhang L, Rifkind JM. A new mode for heme heme interactions in hemoglobin associated with distal perturbations. Biophys. J. 1992;61:750-755.

Biochemistry, Vol 48, No. 14 (April 14, 2009): pg. 3120-3126. DOI. This article is (c) American Chemical Society and permission has been granted for this version to appear in e-Publications@Marquette. American Chemical Society does not grant permission for this article to be further copied/distributed or hosted elsewhere without the express permission from American Chemical Society. 
${ }^{48}$ Ramadas N, Rifkind JM. Molecular dynamics of human methemoglobin: The transmission of conformational information between subunits in an alpha beta dimer. Biophys. J. 1999;76:1796-1811.

${ }^{49}$ Ackers GK, Holt JM, Huang YW, Grinkova Y, Klinger AL, Denisov I. Confirmation of a unique intra-dimer cooperativity in the human hemoglobin alpha(1)beta(1) half-oxygenated intermediate supports the symmetry rule model of allosteric regulation. Prot. Str. Func. Gen. 2000:23-43.

50 Holt JM, Klinger AL, Yarian CS, Keelara V, Ackers GK. Asymmetric distribution of cooperativity in the binding cascade of normal human hemoglobin. 1. Cooperative and noncooperative oxygen binding in $\mathrm{Zn}$ substituted hemoglobin. Biochemistry. 2005;44:11925-11938.

51 Yun KM, Morimoto H, Shibayama N. The contribution of the asymmetric alpha 1 beta 1 half-oxygenated intermediate to human hemoglobin cooperativity. J. Biol. Chem. 2002;277:1878-1883.

52 Bettati S, Mozzarelli A. T state hemoglobin binds oxygen noncooperatively with allosteric effects of protons, inositol hexaphosphate, and chloride. J. Biol. Chem. 1997;272:32050-32055.

53 Dantsker D, Roche C, Samuni U, Blouin G, Olson JS, Friedman JM. The position 68(E11) side chain in myoglobin regulates ligand capture, bond formation with heme iron, and internal movement into the xenon cavities. J. Biol. Chem. 2005;280:38740-38755.

${ }^{54}$ Samuni U, Juszczak L, Dantsker D, Khan I, Friedman AJ, Perez-GonzalezDe-Apodaca J, Bruno S, Hui HL, Colby JE, Karasik E, Kwiatkowski LD, Mozzarelli A, Noble R, Friedman JM. Functional and spectroscopic characterization of half-liganded iron-zinc hybrid hemoglobin: Evidence for conformational plasticity within the $T$ state. Biochemistry. $2003 ; 42: 8272-8288$

Corresponding Author Email Address. Phone: (206) 685-4964, Fax: (206) 685-8665, Email: spiro@chem.washington.edu, Phone: (414) 288-3539, Fax: (414) 288-7066, Email: james.kincaid@marquette.edu

*Present Address. Department of Chemistry, University of Washington, Seattle, WA 98195, USA.

${ }^{* *}$ Advanced Optowave Corporation, P.O. Box 530, Bohemia, NY 11716, USA

\section{Supplementary Material}

Biochemistry, Vol 48, No. 14 (April 14, 2009): pg. 3120-3126. DOI. This article is (C) American Chemical Society and permission has been granted for this version to appear in e-Publications@Marquette. American Chemical Society does not grant permission for this article to be further copied/distributed or hosted elsewhere without the express permission from American Chemical Society. 


\title{
Subunit-Selective Interrogation of CO Recombination in
}

\section{Carbonmonoxy Hemoglobin by Isotope-Edited Time-resolved \\ Resonance Raman Spectroscopy}

\author{
Gurusamy Balakrishnan, ${ }^{1,4}$ Xiaojie Zhao, ${ }^{1,5}$ Edyta Podstawska, ${ }^{2,3}$ Leonard M. Proniewicz, ${ }^{2,3}$ \\ James R. Kincaid, ${ }^{* 2}$ and Thomas G. Spiro ${ }^{* 1,4}$ \\ ${ }^{1}$ Department of Chemistry, Princeton University, Princeton, NJ 08544, USA. \\ ${ }^{2}$ Department of Chemistry, Marquette University, Milwaukee, WI 53233, USA. \\ ${ }^{3}$ Department of Chemistry, Jagiellonian University, Krakow, Poland.
}

Corresponding Author Email Address. Phone: (206) 685-4964, Fax: (206) 685-8665, Email: spiro@chem.washington.edu, Phone: (414) 288-3539, Fax: (414) 288-7066, Email: james.kincaid@marquette.edu 


\section{Simple illustration of the deoxy $v_{4}$ shift for the $\alpha$ - subunits:}
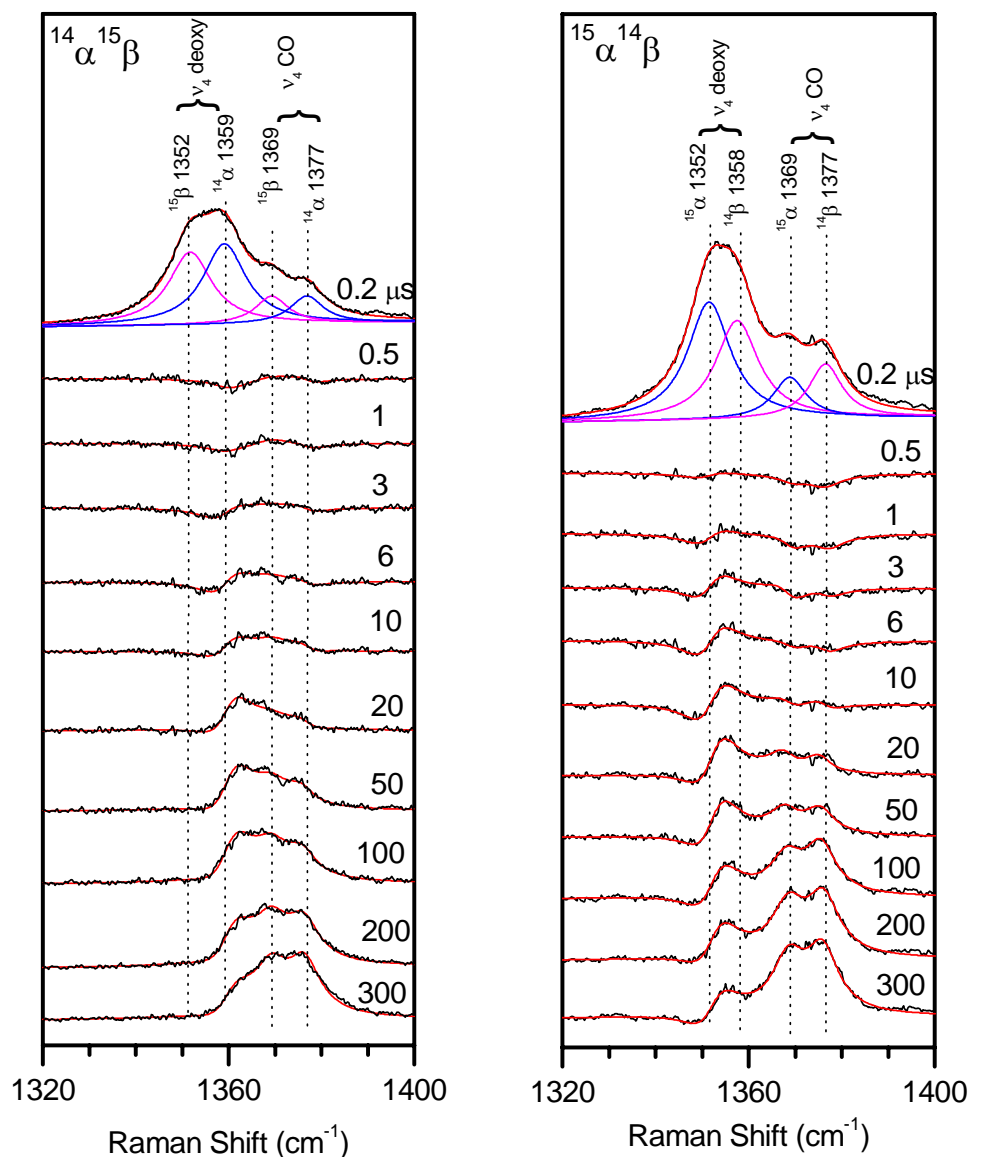

Figure S1. A series of difference spectra (at the indicated delay time minus $0.2 \mu$ s) were generated based on spectral deconvolution (red) and raw data (black), wherein the frequency of the deoxy $\beta$ component were held constant and its intensity were scaled to cancel out while allowing the frequency and intensity of the deoxy $\alpha$ component to completely optimize. The entire temporal profiles for both $\left({ }^{15} \alpha^{14} \beta\right)_{2}$ and $\left({ }^{14} \alpha^{15} \beta\right)_{2}$ hybrids are quite well reproduced by an isolated shift to higher frequency for the $\alpha$ subunits (sigmoidal feature), indicating the distinct frequency shift for $\alpha$ subunits. 